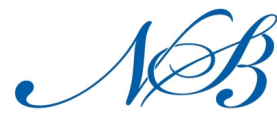

Notulae Scientia Biologicae

\title{
Heterogeneity of Soil and Vegetation in the Urban Habitats of New Industrial Cities in the Desert Landscape of Egypt
}

\author{
Monier Abd EL-GHANI ${ }^{1 *}$, Reinhard BORNKAMM² Nadia EL-SAWAF $^{1}$, \\ Hamdiya TURKY ${ }^{1}$ \\ 'Botany Department, Faculty of Science, Cairo University, Giza 12613, Egypt; elghani@yahoo.com ("correspondingauthor); \\ mmabdelghnai@gmail.com \\ ${ }^{2}$ Institute of Ecology, Technical University Berlin, Rothenburgstr 12, D-12165 Berlin, Germany
}

\begin{abstract}
The relationship between vegetation and soil supporting the habitats in 4 new industrial cities from Egypt were assessed. Five main habitats were distinguished from inner city toward outskirts: lawns, home gardens, public gardens, waste lands and desert outskirts. After application of Twinspan, 26 vegetation groups were identified in the 5 recognized habitats, demonstrating that some groups are characteristic of a certain city, e.g. Asphodelus aestivus - Deverra tortuosa - Thymelaea hirsuta group was confined to the desert habitat of Burg El-Arab city; Thymelaea hirsuta - Linaria albifrons and Atriplex halimus - Atriplex lindleyi subsp. inflata - Suaeda vermiculata - Typha domingensis groups were found in the waste lands of Burg El-Arab city; Conyza bonariensis - Cynodon dactylon - Sonchus oleraceus group in the home garden habitat of $10^{\text {th }}$ Ranadan city; Cynodon dactylon group in the lawns of Burg El-Arab city; Bassia indica - Plantago major group in the public gardens of Burg El-Arab city; Oxalis corniculata - Plantago lagopus group in the public gardens of $10^{\text {th }}$ Ramadan city; Sonchus oleraceus - Cynodon dactylon and Dactyloctenium aegyptium - Leptochloa fusca - Phragmites australis groups in the public gardens of $6^{\text {th }}$ October city. Silt, clay, organic matter, carbonates and carbon contents showed significant differences among the 5 habitats.
\end{abstract}

Keywords: CCA, diversity, flora, soil-vegetation relationships, synanthropic vegetation, Twinspan, urban ecology

\section{Introduction}

The ecological approach considers a city as an ecosystem characterized by its history, structure and function, including both biotic and abiotic components, as well as the cycling and conversion of energy and materials within it. The urban ecosystem contains diverse assemblages of species and habitats from the spontaneous flora of ruderal habitats to the decorative flora of managed areas. Consequently, the term "urban vegetation" refers to all types of spontaneously occurring and cultivated vegetation in cities (Sukopp and Werner, 1983). The biogeographical spectrum of species in cities is very different from that of the surrounding countryside. Cities also have their own spatial organization and distinctive patterns of change through time, which result in patterns of species behaviour, population dynamics and the formation of plant communities, each of which is specific to the urban environment (Sukopp, 2002). Several classification dividing cities into particular urban zones have been proposed (Hejnỳ, 1971; Klotz, 1987) and relationships of flora and vegetation to these zones have been repeatedly studied (Chojnacki, 1991; Goldberg and Gutte, 1988; Pyšek, 1978). Investigations of the flora of whole cities, rather than single habitats, include lists of species and their systematic, biological, ecological and geographic analyses. The current distribution of plants in urban areas is determined by land use. Wittig et al. (1985) distinguished urbanophilous, urbanoneutral and urbanophobous species. Anthropogenic disturbances (created by human activities) include ploughing mowing, burning, grazing and treading by livestock. The anthropogenic environments therefore are generally characterised by higher thermic ranges and lower moisture regime than in the buffered microclimates of the climax vegetation.

Despite increased recognition of the importance of urban vegetation research (Mucina, 1990) few attempts have been made to assess the relative influence of ecological variables on the distribution pattern of urban vegetation. This lack of urban ecological knowledge means that baseline information is scarce and that possibility of applying ecological knowledge in urban planning is limited (Niemalä, 1999). Few studies have tried to relate urban vegetation to environmental factors. Amongst others, the studies of Klotz (1990) and Pyšek (1993), who found that plant species richness in cities is highly correlated to population size, can be highlighted. Effects of land use on vegetation have been investigated in the city of Plymouth (Kent et al., 1999) and in Berlin (Maurer $e t$ al., 2000). More recently, Dana et al. (2002) studied the 
urban vegetation of Almería City in Spain, analysing possible explanatory factors, such as the type of habitat or the level and frequency of disturbance. In the opinion of Aey (1990), the soils of the city centre is made up of filled earth with anthropogenic admixtures (mortar, bricks, tiles, charcoal, bone, pieces of metal, glass, rubble, ceramics) generally ranging from $5 \%$ to $30 \%$. In Brussels' flora, a clear relationship between plant species composition and soil nitrogen, moisture content reaction $(\mathrm{pH})$, light and temperature was detected (Godefroid, 2001). However, in spite of these problems, several plant species are highly successful in urban settings and these, in combination, may give rise to distinctive plant communities (Kay, 1977).

In Egypt, the new cities are considered as natural extension of different Governorates. The essential purpose for the establishment of these cities is the creation of new civilized centres, achieving community stability and economic prosperity, redistribution of population far from Nile Delta narrow strip, establishment of new attraction areas outside the existing cities and villages and curbing the urban infringement upon cultivated areas. No investigation took place in the satellite cities around Cairo, which are still growing and exhibit very special conditions. As a recent emergent field of study, and due to lack of information for plant species development in the urban environments of the Egyptian cities (either old or new settlements), it make the classification of synanthropic vegetation not possible as it took several years of study and calculations (e.g. in Europe it took many years of investigation and special projects were adopted for this task). Until today, the study of natural ecosystems in Egypt has been the main field of scientific interest from the botanical and ecological aspects. In contrast, the study of the vegetation structure and floristic composition in urban environments was poorly documented. Earlier studies on the synanthropic vegetation were carried out by Hejný and Kosinova (1978) in Cairo city. The synanthropic flora of ten new settlements built between 1969 and 1979 on sandy regosol soils in Northeastern Sinai (Egypt) was analyzed by Danin et al. (1982). Shaltout and El-Sheikh (2002) studied the vegetation of the urban habitats in the Nile Delta region (Egypt), where eight major types of habitat (grave yards, demolished houses, abandoned fields, wet and dry refuse areas, railway yards, motor roads and railways) were recognized in the studied area. Also, the flora of gardens and flowerbeds of El-Qanatir Public Park (south Nile Delta) was the subject of El-Sheikh et al. (2004) study. Hamdy et al. (2007) presented the current status of major six botanical gardens established during the $19^{\text {th }}$ century in the metropolitan region of Cairo, addressing their area, land use, landscape architecture and the taxonomic diversity of the species growing in each garden.

Application of quantitative and multivariate analysis techniques in expressing the relationships between the vegetation and environment in the urban cities, whether industrial or not, and their habitats, was pronounced. A quantitative analysis of the flora and plant communities of a representative midwestern urban area in Ohio town (US) was investigated by Whitney (1985). A classification of the sites by Twinspan revealed the existence of three major community types (residual, managed and ruderal) and a variety of minor community subtypes, while ordination yielded several major axes: an inner city-rural dichotomy, a gradient related to soil compaction and a gradient based on the nutrient status of the site. The study concluded that many of the ruderal communities were American analogues of the plant communities, common to urban areas in central Europe. Data on the urban land use composition were then used as environmental variables in an ordination of the data through the Canonical Corresponding Analysis (CCA) to establish the principal land use gradient determining variability in the species data. The application of both, Twinspan and Decorana, to vegetation data of 405 stands representing the variation in eight major types of habitat in the Nile Delta region of Egypt (Shaltout and El-Sheikh, 2002), resulted in 25 vegetation groups that were recognized, and moisture, $\mathrm{pH}$, fertility and texture gradients were indicated for each.

In a previous work, Abd El-Ghani et al. (2011) studied the plant species distribution and spatial habitat heterogeneity in the landscape of 4 new cities in the urbanizing desert ecosystems Egypt: $6^{\text {th }}$ of October, El-Sadat, Burg El-Arab and $10^{\text {th }}$ of Ramadan. Twenty-two Twinspan vegetation groups in the cities were identified and 26 in the five habitats were clearly separated along the first two axes of DCA.

This investigation aims at comparing the floristic composition in different habitats and assessing the soil variables affecting species distribution in each habitat.

\section{Materials and methods}

\section{The study areas}

This study will focus on four of the first (oldest) generation (established between 1977-1982) of new cities from Egypt that can be organized into two deserts: (a) Western Desert, which includes $6^{\text {th }}$ October, Sadat and Burg El-Arab Cities, and (b) Eastern Desert, which includes $10^{\text {th }}$ Ramadan City (Fig. 1). More information about the study sites was presented in Abd El-Ghani et al. (2011).

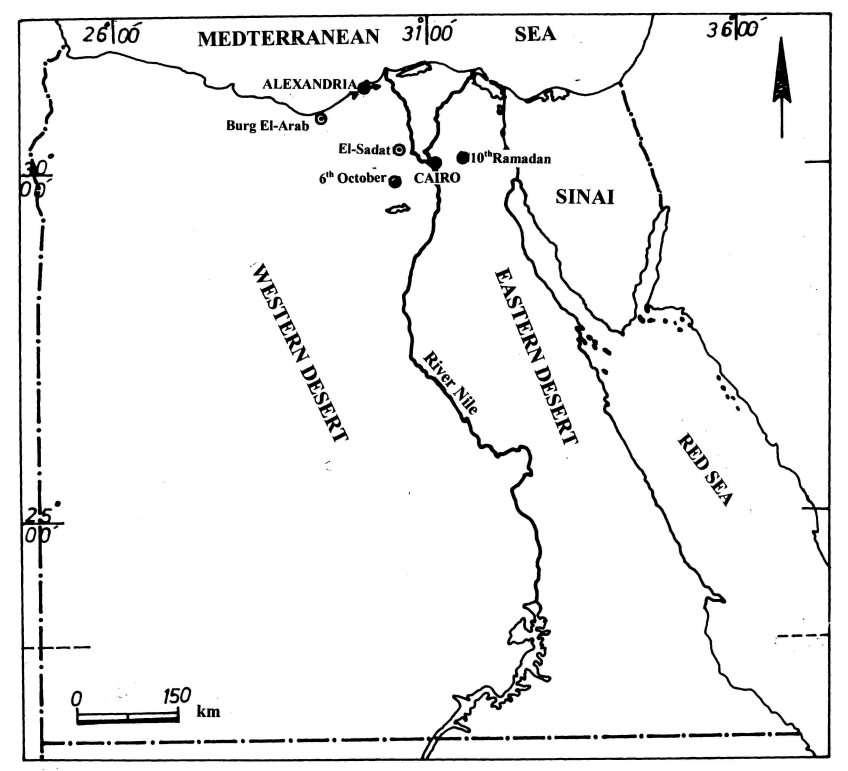

Fig. 1. Location map showing the four studied cities $(\bullet): 6^{\text {th }}$ October, El-Sadat, Burg El-Arab and $10^{\text {th }}$ Ramadan 
28

\section{Vegetation sampling}

Several field trips to the four cities $\left(6^{\text {th }}\right.$ October, El-Sadat, Burg El-Arab and $10^{\text {th }}$ Ramadan) were undertaken. Stratified random sampling technique was employed (Ludwig and Reynold, 1988). Generally, five main habitats were recognized in all cities under investigation: the desert, the waste lands, the home gardens, the lawns and the public gardens. A total of 165 permanent stands $(20 \times 20 \mathrm{~m})$ were selected to represent the apparent variation in the 5 recognized habitats. These stands were distributed as follows: 28 in the desert, 23 in the home gardens, 26 in the lawns, 49 in the waste lands, and 39 in the public gardens. Within each habitat, a number of stands were selected. During each visit, the stands were surveyed and a list of species was recorded. The data were compiled in a raw table containing all the recorded species based on the presence or absence of species for each city. Also, the data were classified according to the prevailing habitats in each city, based on the presence or absence of species. Identification of species was carried out at the herbarium of Cairo University (CAI). Taxonomic nomenclature and life growth forms of each species were according to Täckholm (1974) and Boulos (1995, 1999, 2000, 2002 and 2005).

\section{Soil sampling and analysis}

Three soil samples were collected from each stand at a depth of $0-50 \mathrm{~cm}$. These samples were then pooled, forming one composite sample, air-dried, thoroughly mixed and passed through a $2 \mathrm{~mm}$ sieve to remove gravel and debris, then packed in paper bags, ready for physical and chemical analysis. Three replicates were analyzed for each sample measurement. Soil moisture content was estimated by drying at $105^{\circ} \mathrm{C}$, then the percentage of soil moisture was calculated based on dry weight of the soil (Kaupur and Govil, 2000). Soil texture was determined by the sieve method (Allen $e t$ al., 1974). A known weight of air-dried soil was shaken through a set of sieves and then, the percentages of sand (coarse, medium and fine), silt and clay were calculated. Organic carbon and organic matter were estimated by ignition method (Allen et al., 1974). The percentage of total carbonate content $\left(\mathrm{CO}_{3}\right)$ was determined using $1 \mathrm{~N} \mathrm{HCl}$ (Jackson, 1967). Soil-water extracts (1:5, w/v) were prepared for the determination of soil reaction $(\mathrm{pH})$, total soluble salts, chlorides $(\mathrm{Cl})$, bicarbonates $\left(\mathrm{HCO}_{3}\right)$ and sulphates $\left(\mathrm{SO}_{4}\right)$. Soil reaction was estimated by using a $\mathrm{pH}$-meter which was calibrated before each measurement. The electrical conductivity was measured by electric conductivity meter then the percentage was calculated (Allen et al., 1974). Chlorides were estimated by direct titration against $0.01 \mathrm{~N}$ $\mathrm{AgNO}_{3}$ solution using $5 \%$ potassium chromate as an indicator (Hazen, 1989). Bicarbonates were estimated by titration against $0.1 \mathrm{~N} \mathrm{HCl}$ using methyle orange as an indicator (Maff, 1986). Sulphates were determined turbidimetrically as barium sulphate at $470 \mathrm{~nm}$ (Verma et al., 1977).

\section{Data analysis}

In order to obtain an effective analysis of the floristic composition and related environmental factors, both classification and ordination techniques were employed. Five data matrices were used: in the desert habitat ( 28 stands x 123 species), in the waste lands habitat (49 stands $\mathrm{x} 172$ species), in the home gardens habitat (23 stands $\mathrm{x} 113$ species), in the lawns habitat (26 stands $\mathrm{x} 104$ species) and in the public gardens habitat (39 stands x 133 species). Each floristic data matrix was then subjected to classification by Two-Way Indicator Species Analysis (Twinspan) using the default settings of the computer program PC-ORD for Windows version 4.14 (McCune and Mefford, 1999). In this study, the default option of the computer program Canoco software version 3.12 (Ter Braak, 1987 and 1990) was used for all ordinations. The relationships between vegetation gradients and the studied environmental variables can be indicated on the ordination diagram produced by CCA biplot. A Monte Carlo permutation test 499 permutations; Ter Braak, 1986 and 1990) was used to test for significance of the eigenvalues of the first canonical axis. Inter-set correlations from the CCA's were therefore used to assess the importance of the environmental variables (Jongman et al., 1987).

All data variables were assessed for normality (SPSS for Windows version 10.0) prior to the CCA analysis and appropriate transformations were performed when necessary to improve normality according to Zar (1984). Fourteen environmental variables were included: moisture content (MC), soil reaction ( $\mathrm{pH})$, total soluble salts (TSS), chlorides $\left(\mathrm{Cl}^{-}\right)$, total carbonates $\left(\mathrm{CO}_{3}\right)$, bicarbonates $\left(\mathrm{HCO}_{3}\right)$, organic carbon $(\mathrm{C})$, organic matter $(\mathrm{OM})$, sulphates $\left(\mathrm{SO}_{4}\right)$, coarse sand (CS), medium sand (MS), fine sand (FS), silt and clay. The Twinspan vegetation groups were subjected to ANOVA (One-Way Analysis of Variance), based on soil variables, to find out whether there were significant variations among groups. Analysis of variance provides an insight into the nature of variation of natural events, which is possibly of even greater value than the knowledge of the method as such (Sokal and Rohlf, 1981). Pearson's product-moment correlation coefficient was calculated to evaluate the relationship between the environmental parameters. Species richness $(\mathrm{SR})$ within each separated Twinspan vegetation group was calculated as the average number of species per stand. The Shannon-Wiener diversity index was calculated from the formula $H^{\prime}=-\Sigma P \mathrm{i} \ln P \mathrm{i}$ (Pielou, 1975), where: $\mathrm{H}^{\prime}$ is Shannon-Wiener diversity index and $\mathrm{Pi}$ is the presence of the $\mathrm{i}^{\text {th }}$ species.

\section{Results}

\section{Species distribution within habitats}

Five main urban habitats (from inner city toward outskirts) were distinguished: lawns, home gardens, public gardens, waste lands and desert outskirts. The most speciesrich habitat was the waste lands (172 species), while the total number of species varied from 104 in the lawns and 113 home gardens, to 123 in the desert and 133 in the public gardens (Table 1). Annuals constituted the main bulk of the flora. They showed remarkable occurrence $(>50 \%$ of the flora) in home gardens (60.2\%), followed by public gardens (55.6\%) and lawns (52.9\%). Perennial herbs and woody perennials dominated in the desert habitat $33.3 \%$ for the former and $31.7 \%$ for the latter) than in any other habitats. Asteraceae, Poaceae, Chenopodiaceae and Fabaceae were the most species-rich families and their species were represented in all habitats (Table 1). These families constituted $>50 \%$ of the recorded flora in the lawns and public gardens habitat, and were equally represented in the desert and home gardens. Species of some families showed notable presence in certain 
habitats, e.g., Zygophyllaceae in the desert and home gardens, Boraginaceae in the desert, Cyperaceae in lawns and Convolvulaceae and Apiaceae in the waste lands.

In the desert habitat, Bassia indica, Aizoon canariense, Bassia muricata, Senecio glaucus and Zygophyllum simplex were among the most important annuals. Whereas Launaea nudicaulis, Hyoscyamus muticus, Polycarpaea repens, Stipagrostis plumosa and Cynanchum acutum subsp. acutum were among the common perennial herbs, Deverra tortuosa, Tamarix nilotica, Farsetia aegyptia and Pulicaria undulata were the most important woody perennials. In the home gardens, among the most important recorded annuals were Eragrostis pilosa, Conyza bonariensis, Malva parviflora, Sonchus oleraceus and Bidens pilosa. As for perennial herbs, Cynodon dactylon, Cenchrus ciliaris and Plantago major were the most important ones. Among the important woody perennials were Ficus nitida, Dodonaea viscosa, Nerium oleander and Phoenix dactylifera. For the lawns, Conyza bonariensis, Portulaca oleracea, Malva parviflora, Amaranthus lividus and Plantago lagopus were of common annuals.
Cynodon dactylon, Cyperus rotundus, Cenchrus ciliaris and Convolvulus arvensis were among the most important perennial herbs, while Nerium oleander and Delonix regia were the most common woody perennials. In the waste lands, Bassia indica, Sonchus oleraceus, Conyza bonariensis, Malva parviflora, Chenopodium murale and Amaranthus lividus were the most important annuals. Perennial herbs included, amongst others: Launaea nudicaulis, Cynodon dactylon and Imperata cylindrica, Cenchrus ciliaris and Cynanchum acutum subsp. acutum. Woody perennials exhibited xerophytic nature such as Tamarix nilotica, Pluchea dioscoridis, Deverra tortuosa and Farsetia aegyptia. Among the most common annuals in the public gardens, Eragrostis pilosa, Conyza bonariensis, Malva parviflora, Plantago lagopus, Amaranthus lividus and Sonchus oleraceus occurred. Whereas Cynodon dactylon, Cenchrus ciliaris, Convolvulus arvensis, Dichanthium annulatum and Plantago major were the most important perennial herbs, Ficus nitida, Delonix regia, Nerium oleander, Phoenix dactylifera and Pluchea dioscoridis were the important woody perennials.

Table 1. Summary of the floristic structure in the 5 habitats: $D=D e s e r t, H G=H o m e$ gardens, $L=L a w n s, W L=W a s t e$ lands and PG=Public gardens. Figures between parentheses are the percentages of the total, NS=Not significant numbers

\begin{tabular}{|c|c|c|c|c|c|}
\hline Habitats & $\mathrm{D}$ & HG & $\mathrm{L}$ & WL & PG \\
\hline Total number of stands & 28 & 23 & 26 & 49 & 39 \\
\hline Total number of species & 123 & 113 & 104 & 172 & 133 \\
\hline \multicolumn{6}{|l|}{ (I) Growth forms } \\
\hline i) Annuals & $43(35.0)$ & $68(60.2)$ & $55(52.9)$ & $80(46.5)$ & $74(55.6)$ \\
\hline ii) Perennial herbs & $41(33.3)$ & $25(22.1)$ & $33(31.7)$ & $50(29.1)$ & $34(25.6)$ \\
\hline iii) Woody perennials & $39(31.7)$ & $20(17.7)$ & $16(15.4)$ & $42(24.4)$ & $25(18.8)$ \\
\hline \multicolumn{6}{|l|}{ (II) Species-rich families } \\
\hline Asteraceae & 23 & 12 & 12 & 26 & 16 \\
\hline Poaceae & 19 & 27 & 28 & 28 & 31 \\
\hline Chenopodiaceae & 12 & 5 & 5 & 13 & 6 \\
\hline Fabaceae & 6 & 11 & 10 & 12 & 14 \\
\hline Brassicaceae & 5 & 5 & NS & 8 & 6 \\
\hline Euphorbiaceae & NS & NS & 5 & 7 & 8 \\
\hline Zygophyllaceae & 4 & 8 & NS & NS & NS \\
\hline Boraginaceae & 4 & NS & NS & NS & NS \\
\hline Cyperaceae & NS & NS & 5 & NS & NS \\
\hline Convolvulaceae & NS & NS & NS & 5 & NS \\
\hline Apiaceae & NS & NS & NS & 5 & NS \\
\hline
\end{tabular}

\section{Classification of the vegetation}

Application of Twinspan yielded 26 vegetation groups in the identified habitats (Fig. 2) which were described as follows: in the desert habitats: (A) Asphodelus aestivus Deverra tortuosa - Thymelaea hirsuta, (B) Anabasis articulata, (C) Tamarix nilotica, and (D) Forsskaolea tenacissima; in the waste lands: (A) Thymelaea hirsuta - Linaria albifrons, (B) Cynodon dactylon - Malva parviflora - Polypogon monspeliensis - Sonchus oleraceus, (C) Bassia indica - Launaea nudicaulis, (D) Convolvulus lanatus - Deverra tortuosa - Launaea nudicaulis, (E) Imperata cylindrica - Alhagi graecorum, and (F) Atriplex halimus - Atriplex lindleyi subsp. inflata - Suaeda vermiculata - Typha domingensis; in the home gardens: (A) Cynodon dactylon, (B) Conyza bonariensis - Cynodon dactylon
- Sonchus oleraceus, (C) Cynodon dactylon - Eragrostis pilosa, (D) Bidens pilosa - Eragrostis pilosa, and (E) Dactyloctenium aegyptium - Portulaca oleracea; in the lawns: (A) Cynodon dactylon - Portulaca oleracea, (B) Cynodon dactylon - Nerium oleander - Plantago lagopus, (C) Cynodon dactylon, and (D) Hordeum murinum - Melilotus indicus - Trifolium resupinatum; in the public gardens: (A) Bassia indica Plantago major, (B) Cenchrus ciliaris - Digitaria sanguinalis, (C) Cynodon dactylon, (D) Oxalis corniculata - Plantago lagopus, (E) Malva parviflora - Sisymbrium irio, (F) Sonchus oleraceus - Cynodon dactylon, and (G) Dactyloctenium aegyptium - Leptochloa fusca - Phragmites australis.

Table 2 indicated that none of the characteristic species was recorded in all the recognized habitats. Six species (Asphodelus aestivus, Gymnocarpos decandrus, Anabasis articulata, Calligonum polygonoides, Cyperus alopecuroides and 
30

Forsskaolea tenacissima were confined to the desert habitat with presence values that ranged between 50\% and 100\%. Whereas two cultivated plants (Ficus nitida and Zea mays) and the annuals grass (Poa annua) chatacterized the home gardens with equal presence values (75\%), a group of 6 species (Anagallis arvensis var. arvensis, Lotus glaber, Akocanthera oblongifolia, Convolvulus arvensis, Hordeum murinum and Melilotus indicus) constituted the characteristic species of the lawns habitat with presence values that varied between $66.7 \%$ and $100 \%$. Eleven species showed consistency to the waste lands habitat, of which 7 species with presence values 100\% (Linaria albifrons, Nicotiana glauca, Convolvulus lanatus, Imperata cylindrica, Atriplex lindleyi subsp. inflata, Atriplex halimus and Typha domingensis). In the public gardens, 5 species (Ficus elastica var. decora, Digitaria sanguinalis, Oxalis corniculata, Leptochloa fusca and Phragmites australis) out of the characteristic 8 species attained their highest presence values of $100 \%$.

Apart from the desert habitat, Cynodon dactylon and Malva parviflora exhibited high performance (presence values 71.4-100\%) in the other recognized habitats. The occurrence of Conyza bonariensis, Cenchrus ciliaris, Amaranthus lividus, and Portulaca oleracea in the home gardens, lawns and public gardens habitats with high presence values (71.4-100\%) was remarkable (Table 2). Six common weeds showed higher performance in the home gardens and the public gardens habitats; Chenopodium murale, Sisymbrium irio, Eragrostis pilosa, Bidens pilosa, Plantago major, and Dactyloctenium aegyptium.
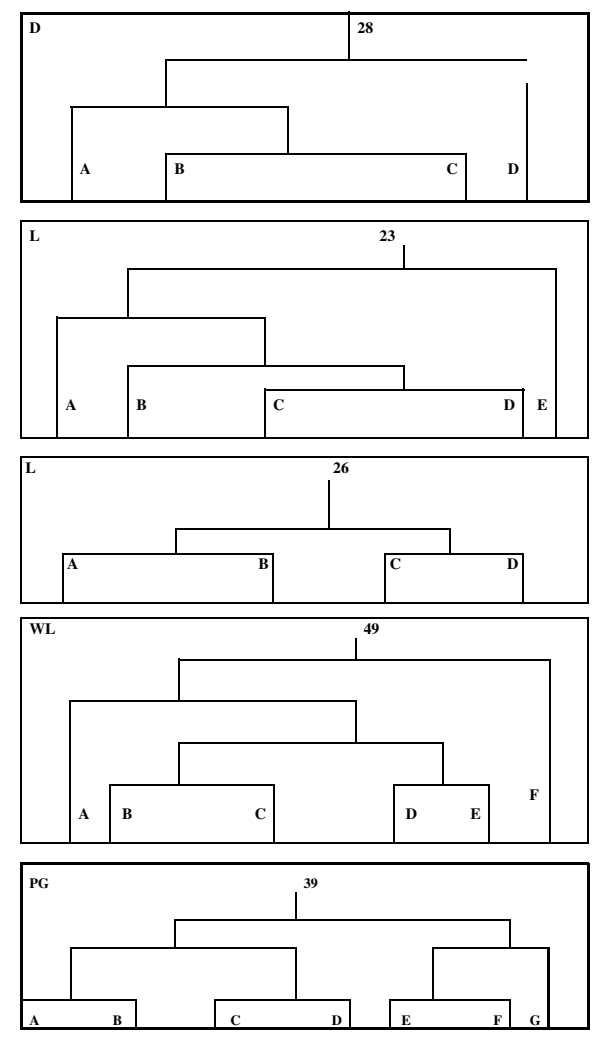

Fig. 2. The 26 vegetation groups yielded after the application of Twinspan for classification of vegetation in the five habitats: $\mathrm{D}=$ Desert, $\mathrm{HG}=$ Home gardens, $\mathrm{L}=$ Lawns, $\mathrm{WL}=\mathrm{W}$ aste lands, and $\mathrm{PG}=$ Public gardens

\section{Soil characteristics of the habitats}

Table 3 summarizes the significant differences in soil features of the 5 habitats. Differences in fine sand, medium sand and sulphate contents were insignificant. The highest number (8) of soil variables with significant differences was in the waste lands habitats, followed by the desert (7) and the public gardens (6). Silt, clay, organic matter, carbonates and carbon contents showed significant differences among the 5 habitats. On the other hand, coarse sand and bicarbonates and total soluble salts showed significant differences in the lawns, desert and waste lands, respectively. Regarding to the species diversity indices, species richness was highly significant $(P=0.007)$ in the public gardens, and Shannon index $(P=0.021)$ with the desert habitat.

\section{Soil-vegetation relationships of the habitats}

The relationship between the vegetation and soil variables was studied using Canonical Correspondence Analysis (CCA). Fig. 3 showed the CCA ordination biplots for the studied habitats with their Twinspan vegetation groups and the examined soil variables. The inter-set correlations resulted from Canonical Correspondence Analysis (CCA) of the examined soil variables in different habitats were displayed in Table 4.

\section{The desert habitat}

The species-environment correlations for the four axes, explaining $52 \%$ of the cumulative variance was determined. CCA axis 1 was positively correlated with total carbonates, organic carbon, organic matter, clay, silt and bicarbonates and negatively with coarse sand. So this axis can be interpreted as total carbonates-coarse sand gradient (Table 4). CCA axis 2 was positively correlated with moisture content and negatively with chlorides. Thus, this axis can be interpreted as moisture contentchlorides gradient. Monte Carlo permutation test (499 permutation) for the eigenvalue of axis 1 found to be significant $(P=0.05)$, indicating that the observed patterns did not arise by chance.

\section{The waste lands habitat}

The species-environment correlations explained $47.7 \%$ of the cumulative variance for the first four axes. CCA axis 1 was positively highly correlated with total carbonates, organic matter, organic carbon and moisture content, and negatively with medium sand. This axis can be defined as total carbonatesmedium sand gradient. CCA axis 2 was positively correlated with coarse sand and negatively with clay, silt and fine sand. Thus, this axis can be defined as coarse sand-clay gradient. Monte Carlo permutation test (499 permutation) for the eigenvalue of axis 1 found to be significant $(P=0.002)$.

\section{The home gardens habitat}

The species-environment correlations explained $59.7 \%$ of the cumulative variance for the first four axes CCA axis 1 was positively correlated with silt, organic matter, organic carbon, $\mathrm{pH}$, clay and moisture content, and negatively with medium sand. So this axis can be defined as silt-medium sand gradient. CCA axis 2 was positively correlated with $\mathrm{pH}$ and negatively with organic carbon and organic matter. Thus, this axis can be defined as $\mathrm{pH}$-organic carbon gradient. Monte Carlo permutation test ( 499 permutation) for the eigenvalue of axis 1 found to be significant $(P=0.05)$. 
Table 2. Characteristic species of Twinspan classification for each of the urban habitats studied. Letters between parentheses are the Twinspan vegetation groups, figures are the highest presence percentage of each species in the habitats' vegetation groups

\begin{tabular}{|c|c|c|c|c|c|}
\hline Habitats & Desert & Home gardens & Lawns & Waste lands & Public gardens \\
\hline Total number of stands & 28 & 23 & 26 & 49 & 39 \\
\hline Total number of Twinspan groups & 4 & 5 & 4 & 6 & 7 \\
\hline Asphodelus aestivus Bort. & $100(\mathrm{~A})$ & & & & \\
\hline Deverra tortuosa (Desf.) DC. & $100(\mathrm{~A})$ & & & $100(\mathrm{~A})$ & \\
\hline Thymelaea hirsuta (L.) Endl. & $100(\mathrm{~A})$ & & & $100(\mathrm{~A})$ & \\
\hline Gymnocarpos decandrus Forssk. & $80(\mathrm{~A})$ & & & & \\
\hline Suaeda vermiculata Forssk. ex J. F.Gmel. & $80(\mathrm{~A})$ & & & $100(\mathrm{~F})$ & \\
\hline Anabasis articulata (Forssk.) Moq. & $50(\mathrm{~B})$ & & & & \\
\hline Farsetia aegyptia Turra & $50(\mathrm{~B})$ & & & $75(\mathrm{D})$ & \\
\hline Tamarix nilotica (Ehrenb.) Bunge & $90(\mathrm{~B})$ & & & $75(\mathrm{C})$ & \\
\hline Zilla spinosa (L.) Prantl & $50(\mathrm{~B})$ & & & $75(\mathrm{D})$ & \\
\hline Bassia indica (Wight) A.J.Scott & $80(\mathrm{C})$ & & & $71.4(\mathrm{C})$ & $100(\mathrm{~A})$ \\
\hline Launaea nudicaulis (L.) Hook.f. & $80(\mathrm{C})$ & & & $100(\mathrm{C})$ & \\
\hline Calligonum polygonoides $\mathrm{L}$. & $70(\mathrm{C})$ & & & & \\
\hline Pulicaria undulata (L.) C. A. Mey. subsp. undulata & $70(\mathrm{C})$ & & & $75(\mathrm{D})$ & \\
\hline Cyperus alopecuroides Rottb. & $100(\mathrm{D})$ & & & & \\
\hline Dichanthium annulatum (Forssk.) Stapf & $100(\mathrm{D})$ & & & & $100(\mathrm{C})$ \\
\hline Forskaolea tenacissima $\mathrm{L}$. & $100(\mathrm{D})$ & & & & \\
\hline Nerium oleander $\mathrm{L}$. & $100(\mathrm{D})$ & & $83.3(\mathrm{~B})$ & & \\
\hline Cynodon dactylon (L.) Pers. & & $100(\mathrm{~A})$ & $100(\mathrm{~A})$ & $71.4(\mathrm{~B})$ & $100(\mathrm{~A})$ \\
\hline Chenopodium murale $\mathrm{L}$. & & $75(\mathrm{~A})$ & & & $83.3(\mathrm{E})$ \\
\hline Ficusnitida Thunb. & & $75(\mathrm{~A})$ & & & \\
\hline Malva parviflora $\mathrm{L}$. & & $75(\mathrm{~A})$ & $75(\mathrm{C})$ & $71.4(\mathrm{~B})$ & $100(\mathrm{~A})$ \\
\hline Poa annua L. & & $75(\mathrm{~A})$ & & & \\
\hline Polypogon monspeliensis (L.) Desf. & & $75(\mathrm{~A})$ & & $71.4(\mathrm{~B})$ & \\
\hline Senecio glauca $\mathrm{L}$. & & $75(\mathrm{~A})$ & $66.7(\mathrm{~B})$ & & \\
\hline Sisymbrium irio L. & & $75(\mathrm{~A})$ & & & $100(\mathrm{E})$ \\
\hline Sonchusoleraceus $\mathrm{L}$. & & $100(\mathrm{~A})$ & & $71.4(\mathrm{~B})$ & $100(\mathrm{~F})$ \\
\hline Conyza bonariensis (L.) Cronquist & & $100(\mathrm{~B})$ & $75(\mathrm{C})$ & & $83.3(\mathrm{~B})$ \\
\hline Eragrostispilosa (L.) P.Beauv. & & $100(\mathrm{C})$ & & & $100(\mathrm{~A})$ \\
\hline Cenchrus ciliaris $\mathrm{L}$. & & $83.3(\mathrm{C})$ & $85.7(\mathrm{~A})$ & & $100(\mathrm{~A})$ \\
\hline Bidenspilosa $\mathrm{L}$. & & $100(\mathrm{D})$ & & & $100(\mathrm{~A})$ \\
\hline Plantago major $\mathrm{L}$. & & $83.3(\mathrm{D})$ & & & $100(\mathrm{~A})$ \\
\hline Amaranthuslividus $\mathrm{L}$. & & $75(\mathrm{E})$ & $71.4(\mathrm{~A})$ & & $83.3(\mathrm{~B})$ \\
\hline Dactyloctenium aegyptium (L.) Willd. & & $75(\mathrm{E})$ & & & $100(\mathrm{G})$ \\
\hline Portulaca oleracea L. & & $75(\mathrm{E})$ & $92.9(\mathrm{~A})$ & & $83.3(\mathrm{~B})$ \\
\hline Zeamays L. & & $75(\mathrm{E})$ & & & \\
\hline Plantago lagopus $\mathrm{L}$. & & & $83.3(\mathrm{~B})$ & & $100(\mathrm{~A})$ \\
\hline Anagallis arvensis $\mathrm{L}$ var. arvensis & & & $66.7(\mathrm{~B})$ & & \\
\hline Lotus glaber Mill. & & & $100(\mathrm{~B})$ & & \\
\hline Akocanthera oblongifolia (Hochst.) Codd. & & & $75(\mathrm{C})$ & & \\
\hline Convolvulus arvensis $\mathrm{L}$. & & & $75(\mathrm{C})$ & & \\
\hline Hordeum murinum $\mathrm{L}$. & & & $100(\mathrm{D})$ & & \\
\hline Melilotus indicus (L.) All. & & & $100(\mathrm{D})$ & & \\
\hline Trifolium resupinatum $\mathrm{L}$. & & & $100(\mathrm{D})$ & & $83.3(\mathrm{E})$ \\
\hline Linaria albifrons (Sm.) Spreng. & & & & $100(\mathrm{~A})$ & \\
\hline Nicotiana glauca R.C. Graham & & & & $100(\mathrm{~A})$ & \\
\hline Cynanchum acutum L. subsp. acutum & & & & $56(\mathrm{C})$ & \\
\hline Convolvuluslanatus Vahl & & & & $100(\mathrm{D})$ & \\
\hline Polycarpaea repens (Forssk.) Asch.and Schweinf. & & & & $75(\mathrm{D})$ & \\
\hline Imperata cylindrica (L.) Raeusch. & & & & $100(\mathrm{E})$ & \\
\hline Alhagigraecorum Boiss. & & & & $85.3(\mathrm{E})$ & \\
\hline Artemisia monosperma Delile & & & & $71.4(\mathrm{E})$ & \\
\hline $\begin{array}{c}\text { Atriplex lindleyi Moq. subsp. inflata (F.Mull.) } \\
\text { P.G.Wilson }\end{array}$ & & & & $100(\mathrm{~F})$ & \\
\hline Atriplex halimus $\mathrm{L}$. & & & & $100(\mathrm{~F})$ & \\
\hline Typha domingensis (Pers.) Poir.ex Steud. & & & & $100(\mathrm{~F})$ & \\
\hline Ficus elastica Roxb.ex Hornem. var. decora & & & & & $100(\mathrm{~A})$ \\
\hline Digitaria sanguinalis (L.) Scop. & & & & & $100(\mathrm{~B})$ \\
\hline Echinochloa colona (L.) Link & & & & & $83.3(\mathrm{~B})$ \\
\hline Delonix regia (Bojer) Raf. & & & & & $64.3(\mathrm{C})$ \\
\hline Oxalis corniculata $\mathrm{L}$. & & & & & $100(\mathrm{D})$ \\
\hline Bromus catharticus Vahl & & & & & $83.3(\mathrm{E})$ \\
\hline Leptochloa fusca (L.) Kunth & & & & & $100(\mathrm{G})$ \\
\hline Phragmites australis (Cav.) Trin. ex Steud. & & & & & $100(\mathrm{G})$ \\
\hline
\end{tabular}


Table 3. ANOVA $P$ values of soil variables, species richness $(\mathrm{SR})$ and Shannon's index $\left(\mathrm{H}^{\prime}\right)$ in the stands representing the groups obtained by Twinspan in all habitats

\begin{tabular}{|c|c|c|c|c|c|c|}
\hline & Soil variables & D & HG & $\mathrm{L}$ & WL & PG \\
\hline $\mathrm{C}$ & 4 & $0.001^{* *}$ & $0.003^{* *}$ & 0.111 & $0.001^{* *}$ & $0.003^{* *}$ \\
\hline Clay & & $0.004^{* *}$ & $0.046^{*}$ & 0.572 & $0.001^{* *}$ & $0.035^{*}$ \\
\hline $\mathrm{CO}_{3}$ & & $0.001^{* *}$ & 0.23 & $0.003^{* *}$ & $0.001^{* *}$ & $0.001^{* *}$ \\
\hline $\mathrm{OM}$ & & $0.001^{* *}$ & $0.003^{* *}$ & 0.111 & $0.001^{* *}$ & $0.003^{* *}$ \\
\hline Silt & & $0.003^{* *}$ & $0.009^{* *}$ & 0.901 & $0.017^{*}$ & 0.144 \\
\hline $\mathrm{Cl}$ & & 0.574 & 0.307 & 0.405 & $0.001^{* *}$ & $0.050^{*}$ \\
\hline $\mathrm{MC}$ & & $0.034^{*}$ & 0.421 & 0.092 & $0.001^{* *}$ & 0.103 \\
\hline & (\%) & 0.112 & 0.591 & $0.011^{*}$ & 0.136 & $0.001^{* *}$ \\
\hline CS & & 0.227 & 0.503 & $0.001^{* *}$ & 0.08 & 0.148 \\
\hline $\mathrm{HCO}_{3}$ & & $0.039^{*}$ & 0.72 & 0.987 & 0.731 & 0.242 \\
\hline TSS & & 0.293 & 0.39 & 0.629 & $0.030^{*}$ & 0.204 \\
\hline FS & & 0.404 & 0.379 & 0.137 & 0.172 & 0.527 \\
\hline MS & & 0.463 & 0.426 & 0.092 & 0.332 & 0.162 \\
\hline $\mathrm{SO}_{4}$ & $\nabla$ & 0.835 & 0.244 & 0.461 & 0.193 & 0.335 \\
\hline SR & & 0.199 & 0.957 & 0.059 & 0.357 & $0.007^{* *}$ \\
\hline $\mathrm{H}^{\prime}$ & & $0.021^{*}$ & 0.952 & 0.439 & 0.314 & 0.082 \\
\hline
\end{tabular}

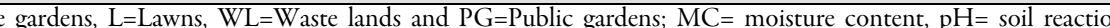
chlorides, $\mathrm{CO}_{3}=$ total carbonates, $\mathrm{HCO}_{3}=$ bicarbonates, $\mathrm{SO}_{4}=$ sulphates, $\mathrm{C}=$ organic carbon, $\mathrm{OM}=$ : organic matter, $\mathrm{CS}=$ coarse sand, $\mathrm{MS}=$ medium sand, and $\mathrm{FS}=$ fine sand; $=P \leq 0.05$ and $^{*}=P \leq 0.01$

\section{The lawns habitat}

The species-environment correlations explained $45.9 \%$ of the cumulative variance for the first 4 axes. CCA axis 1 was positively correlated with carbonates, $\mathrm{pH}$ and moisture content and negatively with fine sand, so this axis can be defined as carbonates-fine sand gradient (Table 4). CCA axis 2 was positively correlated with sulphates, chlorides, total soluble salts and fine sand and negatively with coarse sand. Thus, this axis can be defined as sulphates-coarse sand gradient. Monte Carlo permutation test (499 permutation) for the eigenvalue of axis 1 found to be significant $(P=0.02)$.

\section{Thepublic gardens habitat}

The species-environment correlations (Table 4) for the four axes, explained $46.2 \%$ of the cumulative variance. CCA axis 1 was positively correlated with coarse sand and negatively with total carbonates, silt, clay, total soluble salts and chlorides. So this axis can be defined as coarse sand - total carbonates gradient. CCA axis 2 was positively correlated with medium sand and negatively with organic matter, organic matter, $\mathrm{pH}$, silt, moisture content and clay. Thus, this axis can be defined as medium sandorganic matter gradient. Monte Carlo permutation test (499 permutation) for the eigenvalue of axis 1 found to be significant $(P=0.004)$.

\section{Discussions}

The 26 vegetation groups that were identified in the 5 recognized habitats after application of Twinspan demonstrated that some groups characterized the vegetation of a certain city, e.g. Asphodelus aestivus - Deverra tortuosa Thymelaea birsuta group was confined to the desert habitat of Burg El-Arab city; Thymelaea hirsuta - Linaria albifrons and Atriplex halimus - Atriplex lindleyi subsp. inflata - Suaeda vermiculata - Typha domingensis groups in the waste lands of Burg El-Arab city; Conyza bonariensi - Cynodon dactylon Sonchus oleraceus group in the home garden habitat of $10^{\text {th }}$ Ranadan city; Cynodon dactylon group in the lawns of Burg El-Arab city; Bassia indica - Plantago major group in the public gardens of Burg El-Arab city; Oxalis corniculata -
Plantago lagopus group in the public gardens of $10^{\text {th }}$ Ramadan city; Sonchus oleraceus - Cynodon dactylon and Dactyloctenium aegyptium - Leptochloa fusca - Phragmites australis groups in the public gardens of $6^{\text {th }}$ October city. Comparable vegetation groups were also recognised in the orchards of Siwa Oasis (Abd El-Ghani, 1994) and in the date-palm orchards of Feiran Oasis (Abd El-Ghani, 1998). Yet, different vegetation groups were recognized by El-Sheikh et al. (2004) in the gardens and flowerbeds of El-Qanatir Public Park (south Nile Delta). In addition, the species richness of the urban habitats in the studied cities (11-22 species stands $\left.{ }^{-1}\right)$ was nearly the same as in the Nile Delta region (11-19 species stands ${ }^{-1}$; Shaltout and El-Sheikh, 2002) but higher than that of the weed communities of the common crops in the agricultural land of the Nile Delta (8-12 species stands ${ }^{-1}$; Shaltout and El-Fahar, 1991). In this study, the most common recorded weeds in the lawns, home gardens and public gardens habitats were in consistent with those of Egypt (Boulos and El Hadidi, 1994; El Hadidi and Kosinova, 1971). Apparently, the preponderance of weed flora in the aforementioned habitats was noticed. A slight difference from this framework was reported by Danin et al. (1982) who analysed the synanthropic flora of ten new settlements in NE Sinai. They demonstrated that Conyza canadensis, Conyza bonariensis, Amaranthus gracilis, Digitaria sanguinalis and Portulaca oleracea subsp. nitida were the most common weeds in those areas. The synanthropic flora of NE Sinai displayed a greater similarity to the weed flora of new settlement on the Gulf of Aqaba, than to that of the Bedouin and monastery gardens of the Sinai mountain range and to that of Egypt.

Environmental factors that determined plants species distribution in the urban habitats were scarcely studied. In this study, the application of Canonical Correspondence analysis (CCA) revealed that soil carbonates $\left(\mathrm{CO}_{3}\right)$-sand content was the principal gradient along which the vegetation groups of the desert, waste land, lawns and public garden habitats were distributed, whereas contents of sand and silt affected the home gardens. Other gradients vary from one habitat to the other: moisture content-chloride in the desert, sand-clay in waste lands, $\mathrm{pH}$-organic matter in home gardens, sulphates-sand in lawns and organic matter-sand in public gardens. 

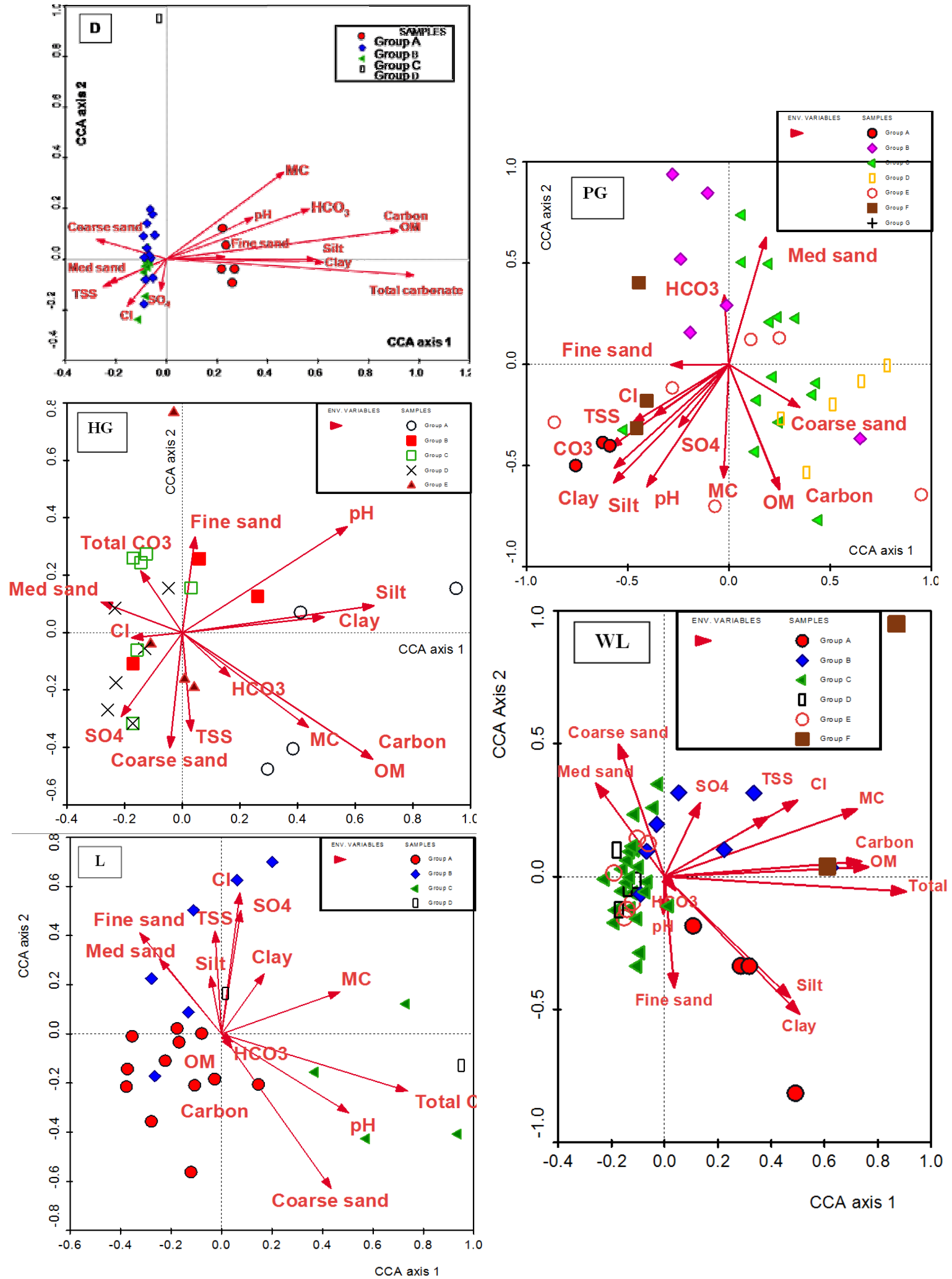

CCA axis 1

Fig. 3. CCA biplots of axes 1 and 2 showing the distribution of stands of the habitats, together with their Twinspan groups and soil variables; $\mathrm{D}=$ Desert, $\mathrm{HG}=$ Home gardens, $\mathrm{L}=\mathrm{Lawn}$, $\mathrm{WL}=\mathrm{W}$ aste lands and $\mathrm{PG}=\mathrm{Public}$ gardens 
Table 4. Inter-set correlation of CCA analysis for the soil variables, together with eigenvalues and species-environment correlation in the 5 habitats; $\mathrm{D}=\mathrm{Desert}$, HG=Home gardens, WL=Waste lands, L=Lawns and PG=Public gardens. For soil abbreviation, see Table 3

\begin{tabular}{|c|c|c|c|c|c|c|c|c|c|c|}
\hline \multirow{2}{*}{$\begin{array}{l}\text { Habitats } \\
\text { Axes }\end{array}$} & \multicolumn{2}{|c|}{$\mathrm{D}$} & \multicolumn{2}{|c|}{ HG } & \multicolumn{2}{|c|}{ WL } & \multicolumn{2}{|c|}{$\mathrm{L}$} & \multicolumn{2}{|c|}{ PG } \\
\hline & 1 & 2 & 1 & 2 & 1 & 2 & 1 & 2 & 1 & 2 \\
\hline Eigenvalues & 0.85 & 0.66 & 0.46 & 0.39 & 0.66 & 0.49 & 0.43 & 0.35 & 0.34 & 0.27 \\
\hline Species - environment correlations & 1.00 & 0.91 & 0.98 & 0.94 & 0.98 & 0.94 & 0.98 & 0.95 & 0.96 & 0.87 \\
\hline $\mathrm{pH}$ & 0.34 & 0.15 & 0.56 & 0.35 & -0.01 & -0.13 & 0.49 & -0.30 & -0.39 & -0.52 \\
\hline $\mathrm{MC}$ & 0.47 & 0.32 & 0.43 & -0.31 & 0.71 & 0.24 & 0.46 & 0.16 & -0.03 & -0.49 \\
\hline TSS & -0.23 & -0.09 & 0.03 & -0.32 & 0.39 & 0.21 & -0.03 & 0.40 & -0.46 & -0.25 \\
\hline $\mathrm{Cl}$ & -0.15 & -0.17 & -0.17 & -0.02 & 0.49 & 0.27 & 0.08 & 0.48 & -0.35 & -0.22 \\
\hline $\mathrm{CO}_{3}$ & 0.98 & -0.06 & -0.14 & 0.20 & 0.89 & -0.05 & 0.72 & -0.22 & -0.56 & -0.36 \\
\hline $\mathrm{HCO}_{3,}$ & 0.57 & 0.18 & 0.16 & -0.15 & 0.04 & -0.05 & 0.04 & -0.03 & -0.02 & 0.30 \\
\hline $\mathrm{SO}_{4}$ & -0.02 & -0.11 & -0.21 & -0.28 & 0.13 & 0.26 & 0.07 & 0.54 & -0.24 & -0.27 \\
\hline (\%) & 0.92 & 0.10 & 0.65 & -0.42 & 0.73 & 0.05 & 0.04 & -0.06 & 0.24 & -0.54 \\
\hline $\mathrm{OM}$ & 0.92 & 0.10 & 0.65 & -0.41 & 0.75 & 0.03 & 0.04 & -0.06 & 0.24 & -0.54 \\
\hline CS & -0.28 & 0.07 & -0.04 & -0.38 & -0.17 & 0.47 & 0.43 & -0.60 & 0.33 & -0.19 \\
\hline MS & -0.25 & -0.10 & -0.28 & 0.10 & -0.25 & 0.33 & -0.24 & 0.29 & 0.17 & 0.55 \\
\hline FS & 0.23 & 0.01 & 0.04 & 0.31 & 0.04 & -0.40 & -0.32 & 0.39 & -0.27 & 0.00 \\
\hline Silt & 0.59 & 0.00 & 0.65 & 0.09 & 0.46 & -0.43 & -0.04 & 0.22 & -0.55 & -0.51 \\
\hline Clay & 0.62 & -0.01 & 0.48 & 0.05 & 0.50 & -0.49 & 0.17 & 0.23 & -0.54 & -0.45 \\
\hline
\end{tabular}

Comparing the soil of the vegetation types at the borders of the Nile Delta with those inside it, Shaltout and El-Sheikh (2002) indicated that silt, organic matter, phosphorus and nitrogen increased, while sand decreased with increased urbanization from the borders of the Nile Delta towards its middle. They suggested that at the border the desert soil merges gradually with the agricultural land of the Nile Delta, where the middle is pure agricultural land. The discharge of organic and inorganic refuses such as dumps, rubbish heaps, debris from buildings, garden refuses, vegetal refuses from kitchens and shops and soild refuses from factories are possible causes for increasing nutrient supply in the urban habitats of the four cities under study. The trampling of soil in the densely-populated urban habitats leads to destruction of soil structure (Frenkel, 1970). As suggested by by Shaltout et al. (1999), the urban vegetation is favoured where disturbance, nutrient and water resources are more abundant. Holzapfel and Schmidt (1990) reported that this relationship may be reversed under more humid conditions.

Results of this study support the idea that plant species composition in urban waste lands is mainly driven by soil nutrient content, soil moisture and soil $\mathrm{pH}$. Urban soils are actually enriched with dirt and construction rubble (mainly cement, bricks and mortar), which leads to an increase in alkalinity (Sukopp et al., 1979). After demolition of buildings, sites are typically graded as a slightly domed area of rubble set into matrix of fine material, which is dominated by lime-based mortar, which leads to neutral to alkaline soils, $\mathrm{pH}$ values typically 6.5-8.0 (Wildlife Trust for Birmingham and the Black Country, 2000). Such observations were also reported by Godefroid et al. (2007) when studying the role of soil microclimatic variables in the distribution patterns of the urban wasteland flora in Bruxeelles (Belgium). Similarly, this study also exhibited the role of $\mathrm{pH}$ in the vegetation of urban habitats. Soils of the studies cities were slightly alkaline $(\mathrm{pH}=7.5-8.2)$ and were significantly correlated with the vegetation in lawns and public gardens habitats (e.g. inner city zone). On the contrary, the soil moisture exhibited significant variation in the vegetation of the desert and waste lands habitats (city outskirts).

\section{References}

Abd El-Ghani MM (1994). Weed plant communities of orchards in Siwa Oasis. Feddes Repertorium 105(5-6):387-398.

Abd El-Ghani MM (1998). Weed communities of date-palm orchards in the Feiran Oasis (south Sinai, Egypt). Fragmenta Floristica et Geobotanica 43(2):257-271.

Abd El-Ghani MM, Bornkamm R, El-Sawaf N, Turky H (2011). Plant species distribution and spatial habitat heterogeneity in the landscape of urbanizing desert ecosystem of Egypt. Urban Ecosystems 14:585-616.

Aey W (1990). Historical approaches to urban ecology, p.113-129. In: Sukopp H, Hejny S, Kowarik I (Eds.), Urban Ecology. SPB Academic Publishing, The Hague.

Allen SE, Grimshaw HM, Parkinson JA, Quarmby C (1974). Chemical Analysis of Ecological Materials. Oxford: Blackwell Scientific Publication.

Boulos L (1995). Flora of Egypt. Checklist. Cairo: Al Hadara Publishing.

Boulos L (1999). Flora of Egypt, Vol. 1. Azollaceae-Oxalidaceae. Cairo: Al Hadara Publishing.

Boulos L (2000). Flora of Egypt, Vol. 2. Geraniaceae-Boraginaceae. Cairo: Al Hadara Publishing.

Boulos L (2002). Flora of Egypt, Vol. 3. Verbinaceae-Compositae. Cairo: Al Hadara Publishing.

Boulos L (2005). Flora of Egypt, Vol. 4. Monocotyledons (Alismataceae-Orchidaceae). Cairo: Al Hadara Publishing.

Boulos L, El-Hadidi MN (1994). The Weed Flora of Egypt. Revised Edition. Cairo: The American University in Cairo Press.

Chojnacki J (1991). Zroznicowanie przestrzenne roslinnosci Warszawy. Wydaw. Univ. Warszawa.

Dana ED, Vivas S, Mota JF (2002). Urban vegetation of Almería City: a contribution to urban ecology in Spain. Landscape and Urban Planning 59:203-216.

Danin A, Weinstein A, Karschon R (1982). The synanthropic flora of new settlements in Northeastern Sinai. I. Composition and origin. Willdenowia 12:57-75. 
El Hadidi MN, Kosinová J (1971). Studies on the weed flora of cultivated land in Egypt. 1. Preliminary survey. Mitteilungen der Botanischen Staatssammlung München 10:354-367.

El-Sheikh MA, El-Halawany EF, Shaltout KH (2004). Flora and vegetation of Qanatir public Park, southern Nile Delta, Egypt. Journal of Environmental Science 27(2):137158.

Frenkel RE (1970). Ruderal Vegetation along some California Roadsides. California: University of California Press.

Godefroid S (2001). Temporal analysis of the Brussels flora as indicator for changing environmental quality. Landscape and Urban Planning 52:203-224.

Godefroid S, Monbaliu D, Koedam N (2007). The role of soil and microclimatic variables in the distribution patterns of urban wasteland flora in Brussels, Belgium. Landscape and Urban Planning 80:45-55.

Goldberg A, Gutte P (1988). Phytosoziologische Charakterisierung städtischer Flachennutzungsstrukturen, dargestellt an einem Transekt durch die Grosstadt Leipzig, p.59-66. In: Zaliberová M (Ed.), Symposium synanthropic flora and vegetation, Veda, Bratislava.

Hamdy R, Abd El-Ghani MM, Yousef TL, El Sayed M (2007). The floristic composition of some historical botanical gardens in the metropolitan of Cairo, Egypt. African Journal of Agricultural Research 2(11):610-648.

Hazen A (1989). On determination of chloride in water. American Journal of Chemistry 2:409-425.

Hejnỳ S (1971). Metodologickỳ pňspěvek $k$ vỳzkumu synantropn květeny a vegtace velkoměsta (na pňkladuPrahy). Zborn. Predn. Zjazdu Slov. Bot. Spoloc., Tisoveč 1970, 2:545-567. Braislava.

Hejný S, Kosinova J (1978). Contribution to synanthropic vegetation of Cairo. Publication of Cairo University Herbarium 7-8:273-386.

Holzapfel C, Schmidt W (1990). Roadside vegetation along transects in the Judean desert. Israel Journal of Botany 39:263-270.

Jackson ML (1967). Soil Chemical Analysis-Advanced Course. Published by the Washington Department of Soil Sciences.

Jongman RH, Ter Braak CJF, Van Tongeren OFG (1987). Data analysis in community and landscape ecology. Wageningen: Pudoc.

Kaupur P, Govil SR (2000). Experimental Plant Ecology ( $1^{\text {st }}$ Edn.). New Delhi: CBS Publishers and Distributors.

Kay QON (1977). Biology of Urban Weeds. British Association for the Advancement of Science, $139^{\text {th }}$ Annual Meeting, Program 49.

Kent M, Stevens RA, Zhang L (1999). Urban plant ecology patterns and processes: a case study of the flora of the City of Plymouth, Devon UK. Journal of Biogeography 26:1281-1298.

Klotz S (1987). Floristische und vegetationskundliche Untersuchungen in Städten der DDR. Düsseldorfer Geobotanische Kolloquien 4:61-69.
Klotz S (1990). Species-area and species-inhabitants relations in European cities, p.99-104. In: Sukopp H, Hejný S, Kowarik I (eds.), Urban ecology: plants and plant communities in urban environments. SPB Publishing, The Hague, Netherlands.

Ludwig GA, Reynold JF (1988). Statistical Ecology. New York: John Wiley.

Maff RB (1986). The Analysis of Agricultural Materials. $3^{\text {rd }}$ Edn. London: HSMO.

Maurer U, Peschel T, Schmitz S (2000). The flora of selected urban land-use types in Berlin and Potsdam with regard to nature conservation in cities. Landscape and Urban Planning 46:209-215.

McCune B, Mefford MJ (1999). PC-ORD for Windows. Multivariate Analysis of Ecological Data. Version 4.14. User's Guide. MjM Software, Oregon, USA.

Mucina L (1990). Urban vegetation research in European COMECON-countries and Yugoslavia: a review, p.23-43. In: Sukopp H, Hejny S, Kowarik I (Eds.) Urban ecology. The Hague: SPB Academic Publishing.

Niemelä J (1999). Ecology and urban planning. Biodiversity and Conservation 8:119-131.

Pielou EC (1975). Ecological Diversity. New York: Wiley, Interscience.

Pyšek A (1978). Ruderální vegetace Velke Plznì. Ms., p. 290 (Kand. dis. práce; depon. in: Knih. BÚČSAV Pruhonice).

Pyšek P (1993). Factors affecting the diversity of flora and vegetation in central European settlements. Vegetatio 106:89-100.

Shaltout KH, El-Fahar R (1991). Diversity and phenology of weed communities in the Nile Delta region. Journal of Vegetation Science 2:385-390.

Shaltout KH, El-Kady HF, El-Sheikh MA (1999). Species diversity of the ruderl habitats in the Nile Delta. Taeckholmia 19(2):203-225.

Shaltout KH, El-Sheikh MA (2002). Vegetation of the urban habilats in the Nile Delta region, Egypt. Urban Ecosystems 6:205-221.

Sokal RR, Rohlf FJ (1981). Biometry. San Francisco: Freeman. Sukopp H (2002). On the early history of urban ecology in Europe. Preslia 74:373-393.

Sukopp H, Werner P (1983). Urban environment and vegetation. In: Holzner W, Werger MJA, Ikusima I (Eds.), Man's impact on vegetation. The Hague: Dr W Junk Publishers.

Sukopp H, Blume HP, Kunick W (1979). The soil, flora, and vegetation of Berlin's waste lands. In: Laurie IC (Ed.), Nature in Cities. Chichester, New-York.

Täckholm V (1974). Students' Flora of Egypt. (2 ${ }^{\text {nd }}$ Edn.). Cairo: Cairo University Press.

Ter Braak CJF (1986). Canonical correspondence analysis: a new eigenvector technique for multivariate direct gradient analysis. Ecology 67:1167-1179.

Ter Braak CJF (1987). CANOCO-A FORTRAN Program for Canonical Community Ordination by [Partial] 
[Deterended] [Canonical] [Correspondence] [Analysis], Wildlife Trust for Birmingham and the Black Country (2000). Principal Community Analysis and Redundancy Analysis, Version 2.1 Agricultural Mathematics Group, Wageningen. Habitat Action Plan.Urban "Wasteland".http://www.wildlifetrus t.org.uk/urbanwt/ecorecord/bap/html/urba.htm.

Ter Braak CJF (1990). Update notes: CANOCO Version 3.1, Wittig R, Diesing D, Gödde M (1985). Urbanophob-UrbanoneutralAgricultural Mathematics Group, Wageningen.

Verma BC, Swaminathan K, Sud KC (1977). An improved turbidimetric procedure for determination of sulpphate in plants and soils. Talanta 24:49-50.

Whitney GG (1985). A quantitative analysis of the flora and plant communities of a representative Midwestern US town. Urban Ecology 9:143-160. Urbanophyil. Das Verhalten der Arten gegenüber dem Lebensraum Stadt Flora 177:265-282.

Zar JH (1984). Biostatistical analysis. $2^{\text {nd }}$ Ed. Englewood Cliffs: Prentice-Hall. 